\title{
GEOSPATIAL TOOLS FOR PREVENTION OF URBAN FLOODS CASE STUDY: RIVER OF EL MALEH (CITY OF MOHAMMEDIA - MOROCCO)
}

\author{
Mohamed Salem Chaabane ${ }^{a}$, Naima Abouali ${ }^{a}$, Taieb Boumeaza ${ }^{b}$, Mohamed Zahouily ${ }^{a}$ \\ ${ }^{a}$ Department of Process Engineering, Faculty of Science and Technics of Mohammedia, Morocco, \\ salimchaabane@gmail.com,abouali_naima@yahoo.fr,mzahouily@gmail.com \\ b Department of Geography, Faculty of Letters and Human Sciences of Mohammedia, Morocco, taiebboumeaza@yahoo.fr
}

KEY WORDS: GIS, Floods Simulation, Modelling hydraulics, DEM, HecRAS, Geo-HecRAS.

\begin{abstract}
:
Today, the prevention and the risk management occupy an important part of public policy activities and are considered as major components in the process of sustainable development of territories. Due to the expansion of IT processes, in particular the geomatics sciences, decision-makers are increasingly requesting for digital tools before, during and after the risks of natural disasters. Both, the geographic information system (GIS) and the remote sensing are considered as geospatial and fundamental tools which help to understand the evolution of risks, to analyze their temporality and to make the right decisions.

The historic events (on 1996, 2002 and 2010) which struck the city of Mohammedia and having caused the consequent damage to vital infrastructure and private property, require a thorough and rational analyze to benefit from it and well manage the floods phenomena. This article present i) the contribution of the geospatial tools for the floods simulation of Oued of el Maleh city at various return periods. These tools allow the demarcation of flood-risk areas and so to make floods simulations in several scenarios (decadal flood, 20-year flood, 50-year flood, 100-year flood, 500-year flood \& also millennial flood) and besides (ii) present a synthesis map combining the territorial stakes superposed on the flood scenarios at different periods of return.
\end{abstract}

\section{MANUSCRIPT}

The assessment of the flooding risk requires an overview of several geosciences, including: geomorphology, hydrology, hydrogeology, climatology ...). A multidisciplinary study combined with a territorial vision of land-use planners and geospatial technologies will undoubtedly make possible to prevent and even mitigate the floods risk. This can consequently have a positive impact on the built and property of citizens. Of course, this assessment may be of a socio-economic nature through the rational determination of risk and damage. This will be doing by various simulating and with a flood reference baseline.

Flooding is a natural phenomenon with an indeterminate frequency. They are growing incredibly expanding, given the impact of climate change. The city of Mohammedia is part of the most strategic coastal axis of the Kingdom of Morocco.

Thus, various industrial facilities exist, notably the country's main refinery, the oil district, the gas warehouses, the sole thermal power station, the national electrolysis and petrochemicals company, the oil port, etc.

Of course, two mouths river are present in the city, to the East and the West. The study is focused on the Oued Maleh which situated near the industrial units mentioned above.

For that purpose, and given the primordial character of the city, this study is contributing to preventive and anticipatory management in order to develop more and more resilient cities capable of dealing with floods disaster. It will provide planners, developers and decision makers a geo-decisional tools capable of simulating floods and treating all possible scenarios.
The Hydraulic data led to the identification of flood-risk areas through the flood simulation tool (HecRAS). A strong combination is now possible with Geographic Information Systems (GIS) to cross all data (Hazard, vulnerability) and model the risk of urban flooding. Therefore, this will have a direct impact on the inhabitants of the city and will allow to warn the decision-makers and to protect the population and its properties from any possible danger.

Besides, GIS in particular, as a component of geospatial technology, is an indispensable tool for screening hazardous areas and for financial estimation of potential damage based on spatial modeling and analysis methods.

\subsection{Study Area}

The city of Mohammedia or Fedala (Old city name) belongs to the region of Casablanca-Settat. Its geographical coordinates are: $33^{\circ} 41$ '23 "North $7^{\circ} 23^{\prime} 23^{\prime}$ West. It is bounded on the North by the Atlantic Ocean, on the East and South by the Province of Ben-Slimane and on the West by the Prefecture of SidiBernoussi.

It is part of the strategic coastal corridor "Kenitra - Casablanca", considering as a dynamic axis for the Kingdom with multiple economic and political stakes. At $70 \mathrm{~km}$ from Rabat and $24 \mathrm{~km}$ from Casablanca, the urban perimeter of the city covers an area of $35 \mathrm{~km}^{2}$. The population of the municipality increased from 187,708 inhabitants in 2004 to 208,612 inhabitants in 2014 according to the global census of the Population and Housing of 2004 and 2014. That's a growth rate of $1.12 \%$. 
As regards to the topography of the study area, it is on a maximal height of $50 \mathrm{~m}$ up to the sea level. The mouth of El Maleh (subject of the study) is illustrated on the concave part (party) of the digital elevation model (DEM) of Mohammedia (Figure1).

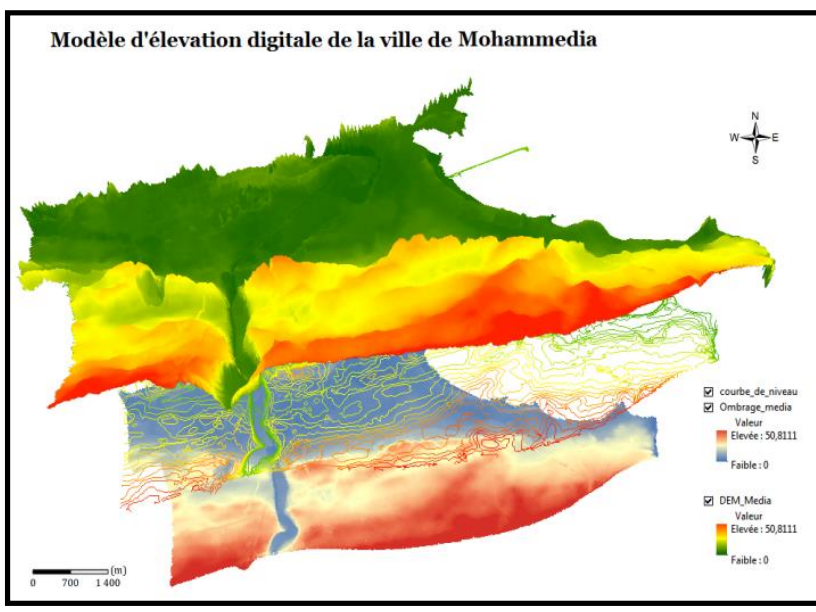

Figure 1. Digital elevation model of the area of the study Mohammedia -

\subsection{Physical frame of the study area}

The study area belongs to the West part of coastal Meseta of Morocco - also called northern (septentrionale in french). It is distinguished by sandy beaches, the flat rocks and a low topography, reaching below the sea level on the wetland.

The geology of the region corresponds to a paleozoic base dated to the Cambrian ( slaty deposits) on which settled successively the Cambrien-Ordovicien ( quarzites ), the deposit of PermoTrias (pélitico-basaltic) of the Cretaceous (marno-limestone) and the Plio-Quaternaire ( gréso-limestone). The set is covered with continental silt. The Primaire folded and tectonized during the Hercynian orogeny constitutes an impermeable substrate, while the discordant post-primary moulding (Cretaceous and PlioQuaternary) constitute a permeable cover.

The soils in the region consist mainly of Hamri (clay soil or welldrained Vertisol), Tirs (Vertisol), Rmel (sandy soil) and Dendoun (calcimorphous soil). At the level of the Oued El Maleh valley and the alluvial zone, the soil is very deep and has a fine texture of $85 \%$ ( $48 \%$ clay and $37 \%$ silts); The soluble salt content exceeds $2 \%$ and the organic matter content is quite high $(2.51 \%)$.

On the other hand, lithological analysis reveals the presence of formations with low porosity (Figure 3) that can harbor permeable zones and consequently the infiltration water coming from precipitation or condensations of atmospheric water vapor.

So, the classification of slopes (Figure 2) is necessary in order to evaluate the flow velocity of rainwater. The analysis indicates a very high slope exceeding $7 \%$ at the mouth of Oued El Maleh, while the overall average is close to $2 \%$.

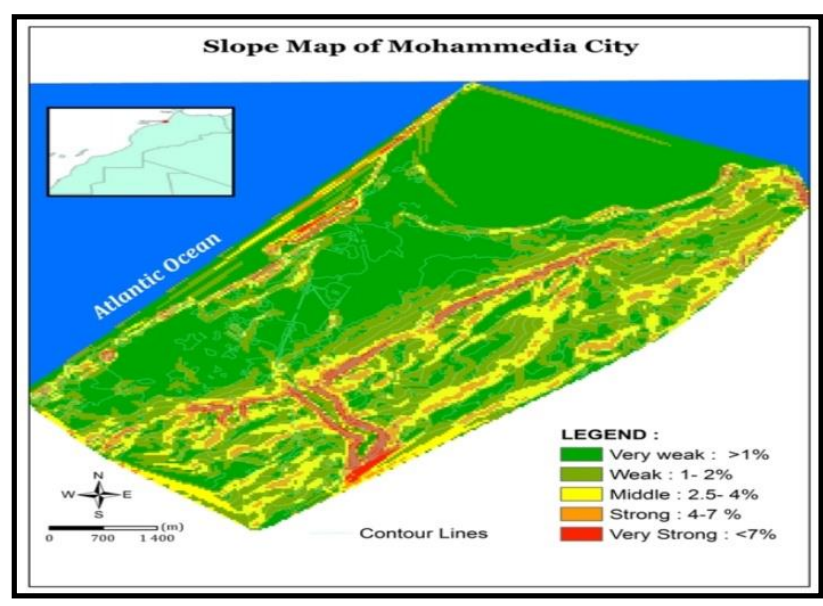

Figure 2. Slopes Map of the study area

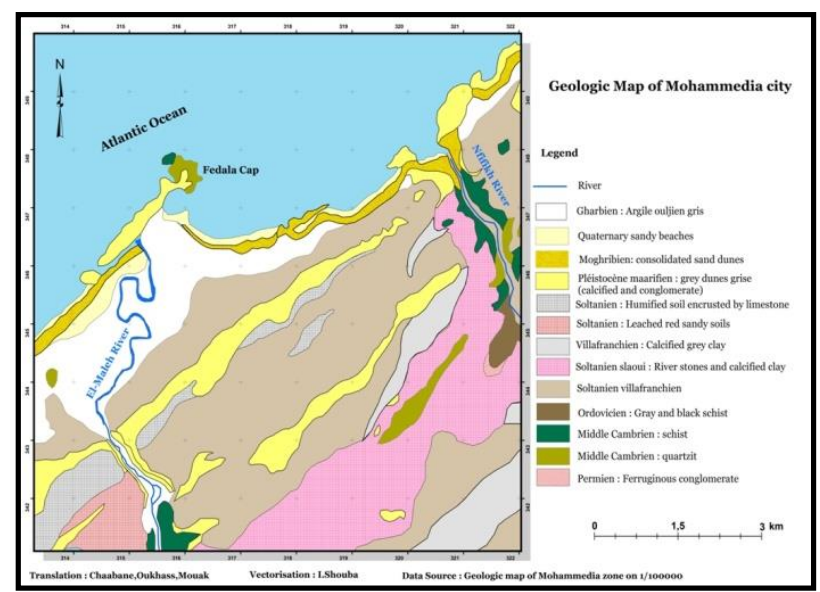

Figure 3. Geological Composition of the Study Area

\subsection{State of the art}

The study area is not chosen arbitrarily. The National Flood Protection Plan (NFPP) ranks Mohammedia among the 50 priority high-risk sites. This zone underwent floods repeatedly in 1996, 2002 and recently in 2010. This unpredictable confusion has caused considerable damage in addition to a glaring socioeconomic handicap. Some Studies on the vulnerability of Mohammedia's territory to natural hazards have already taken place (eg The SIG: a tool for the coastal evaluation at risk of flooding of lands connected to climate change. Case of the coast of Mohammedia; diagnosis of the rough floods of the oued El Maleh of Mohammedia's city on Novembr 2002) While those of an institutional nature are being finalized. The two most common types of risk are the tsunami and floods.

The city of Mohammedia is located on a strategic coastline axis with full mutation. Despite the efforts made by the various ministerial departments and local authorities, Mohammedia remains vulnerable and requires the urgent development of an ideal road map, which incite the stakeholders to multiply efforts by prioritizing this action.

Theoretically, the Risk is defined as the result of an association between hazards (natural phenomenon - ex: flood) and Stakes (people, the properties...).So, to assess properly the flood risk at the city and to see its spatial impact, a decoupling of this natural phenomenon would be doing through a hydrological analysis as well as the development of a stakes map, which include vital 
points of interest. The combination will help planners to good decision-making.

\section{MATERIELS ET METHODES}

The demarcation of flood zones is a dynamic and evolving process. The diagram of their determination is based on technical work (Figure 4) and is confirmed by the digital and geomatics sciences tools.

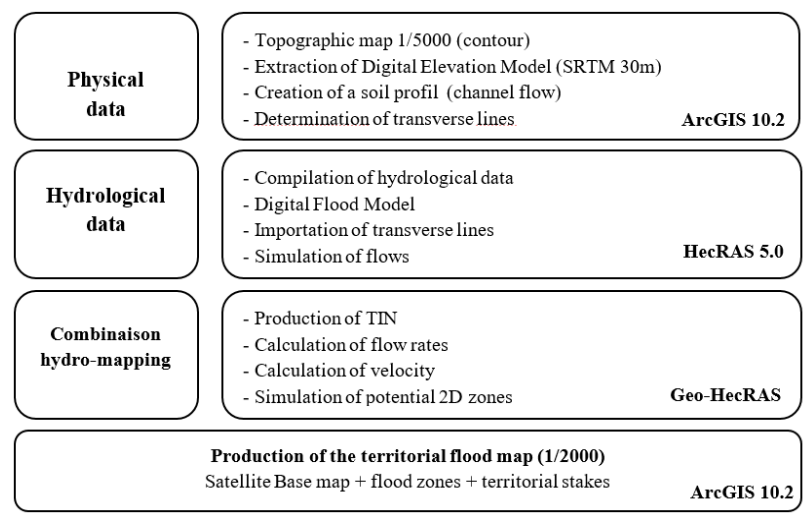

Figure 4. Process of elaboration of the flood Map

\subsection{Digital flood model}

Today, flood risk has become a primary concern for urbanism and territory plan. Of course, and before any projection or urbanization assignment, the precise and fine delineation of the flood zone is an unavoidable priority. At city level where urbanization is almost saturated, planners are now trying to build the city on the city, hence the effect of densification takes place. And doubtless, on the outlines of flood-prone territories, the stakes are becoming more and more important and the establishment of the digital flood models (MNI) or flood-risk areas is reason to be helpeful.

It is true that this MNI, which the extract is below (Figure 5) can be combined with the MNT, could be used in the implementation of Flood Prevention Plans or Urbanization Plans.

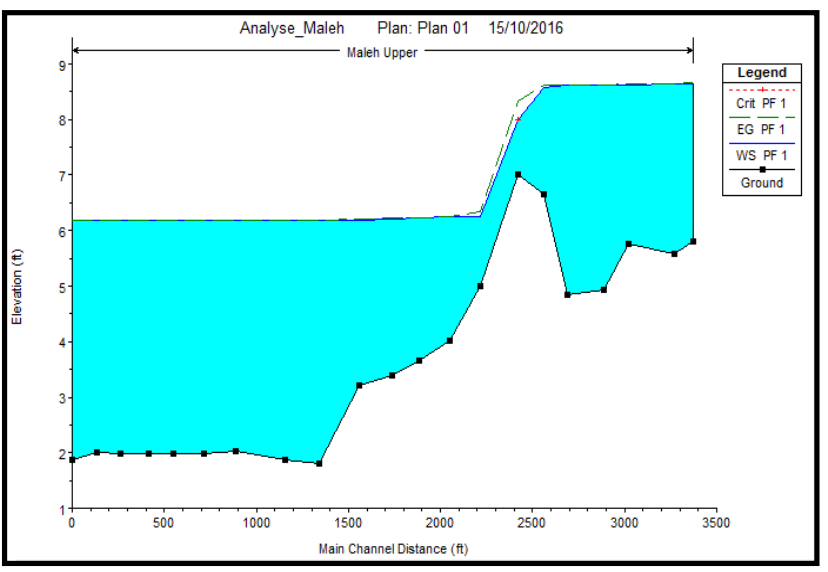

Figure 5. Extract of the Digital Flood Model

\subsection{Flood risk mapping:}

As mentioned above, the risk is a combination with hazard and territorial vulnerabilities. Technically, it is a crossing of the stakes maps and flood maps to determine the level of exposure of a territory to the risk of flooding, especially:

\section{FLOOD RISK MAP = STAKES MAP + FLOOD MAP}

\subsection{The stakes of the study area}

A geographic database (GDB) facilitates the development of territory stakes map. This GBD allows to identify all the economic stakes (industrial sites, warehouses, activities ...), housing, transport networks (national \& regional roads, highway, railway), Hydrological (Wadis flow, shedding channel, groundwater, ...). After the superposition of all these data, the stakes map is produced (figure 6).

In the absence of Lidar data (altimetry detection) and for 3D simulation purposes, an inventory of stakes bound of altimetry buildings is planned later (field survey).

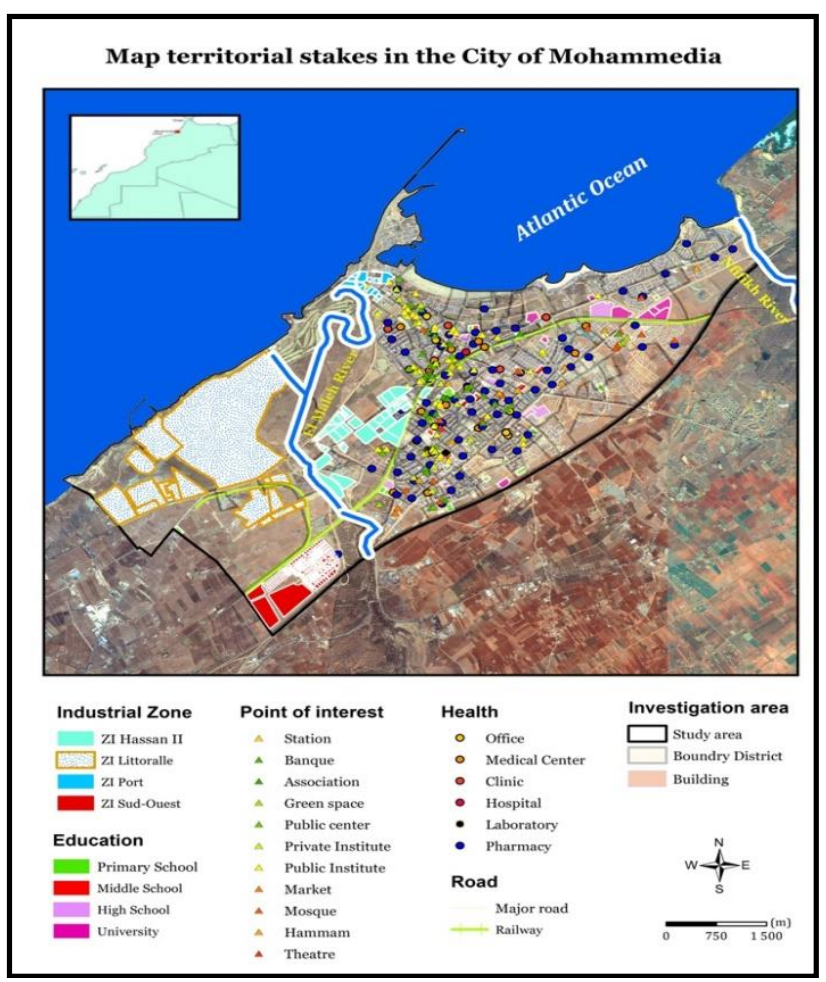

Figure 6. Map territorial stakes in the City of Mohammedia

\section{RESULTS}

In order to determine the flood risk of the City of Mohammedia at different scales, six flood simulation scenarios were considered at various speeds, including a decadal flood (Figure 7), a 20-year flood (Figure 8), a 50-year flood (Figure 9), a 100-year flood (Figure 10), a 500-year flood (Figure 11), and a millennial flood (Figure 12) qualified as exceptional in scope. This peak flow exceeds largely the reference flood of 2002 estimated at $430 \mathrm{~m} / \mathrm{s}$.

So, a crossing with the stakes map took place in order to determine meticulously, for each scenario, the flood risk. 


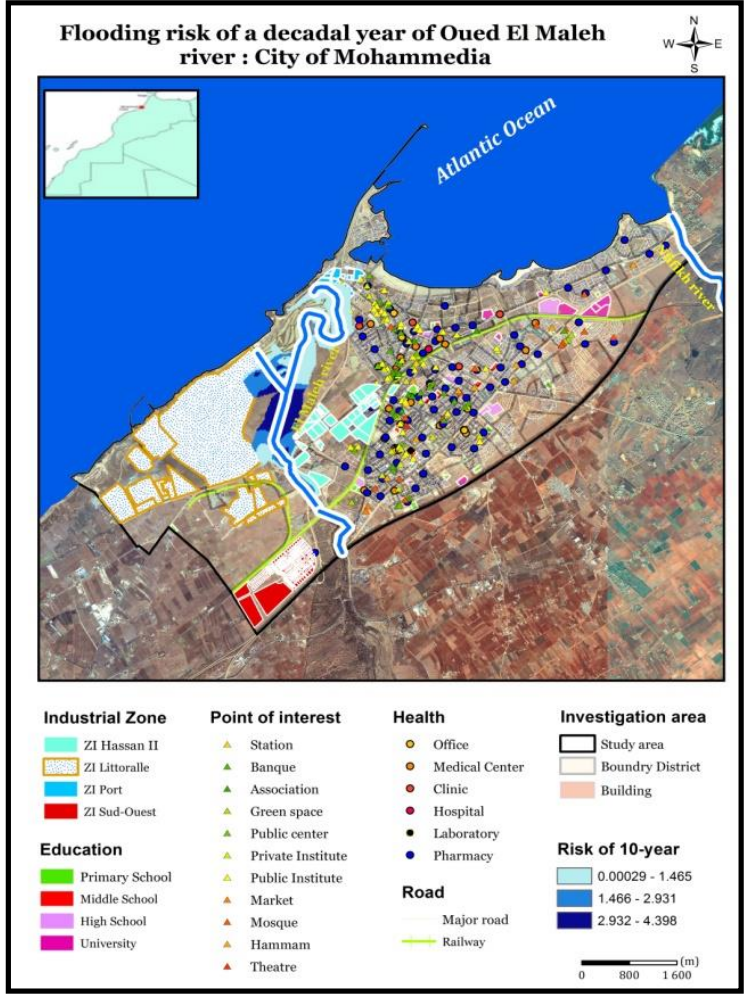

Figure 7. Flooding risk of a decadal year

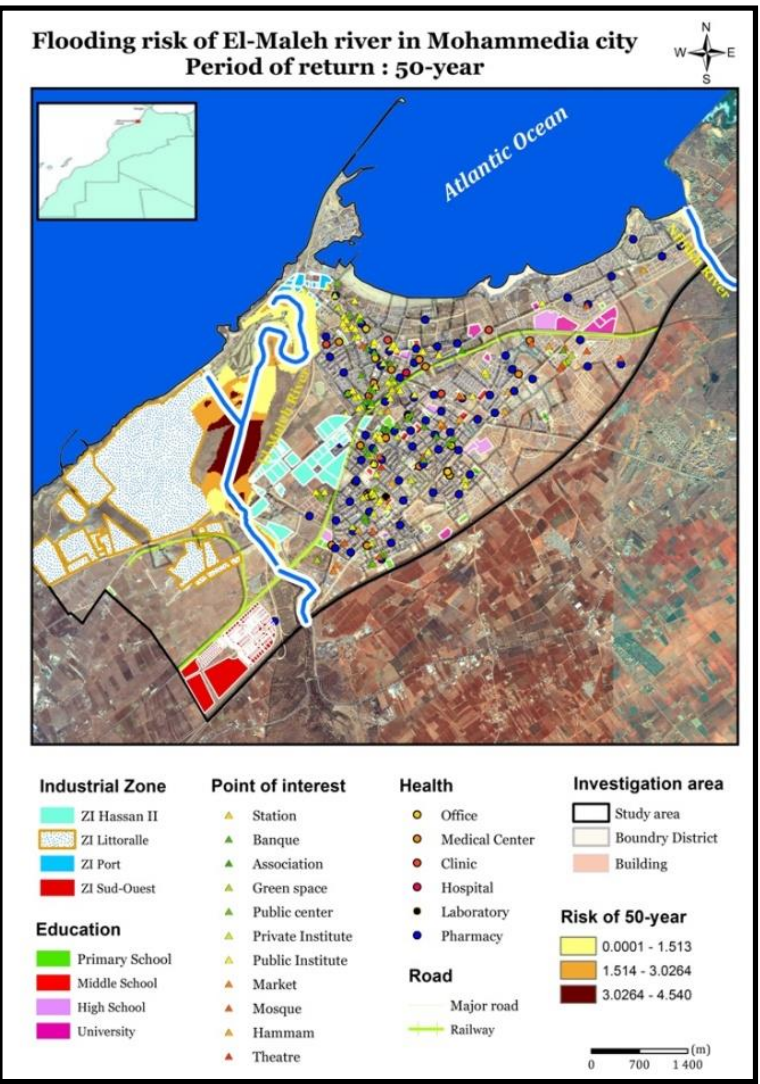

Figure 9. Flooding risk of a 50-year

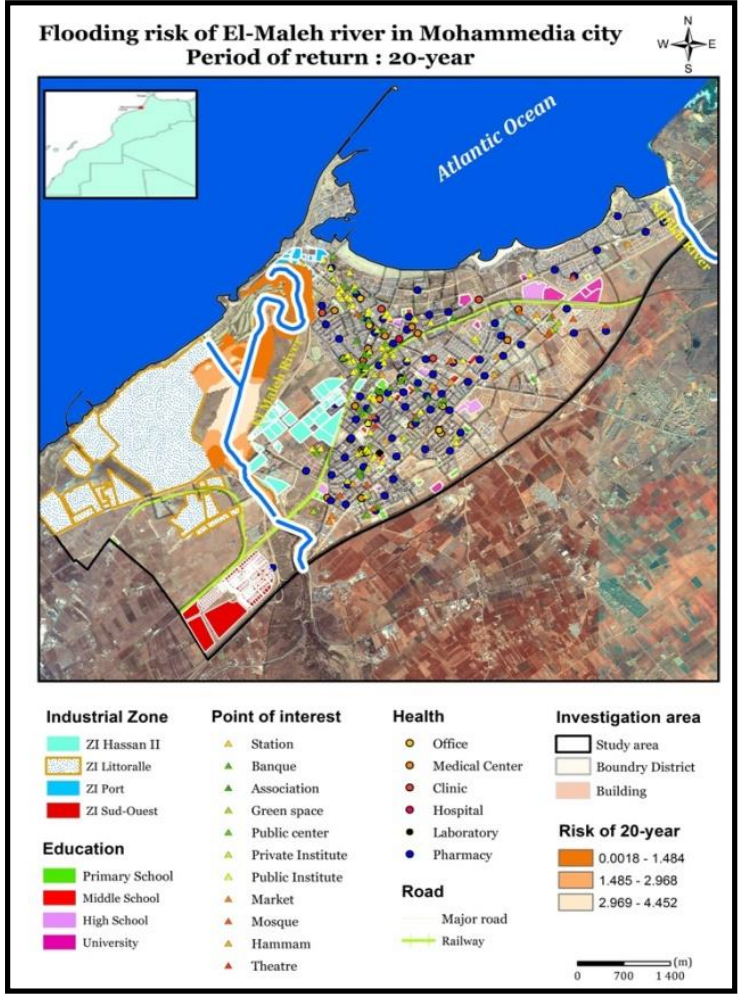

Figure 8. Flooding risk of a 20-year

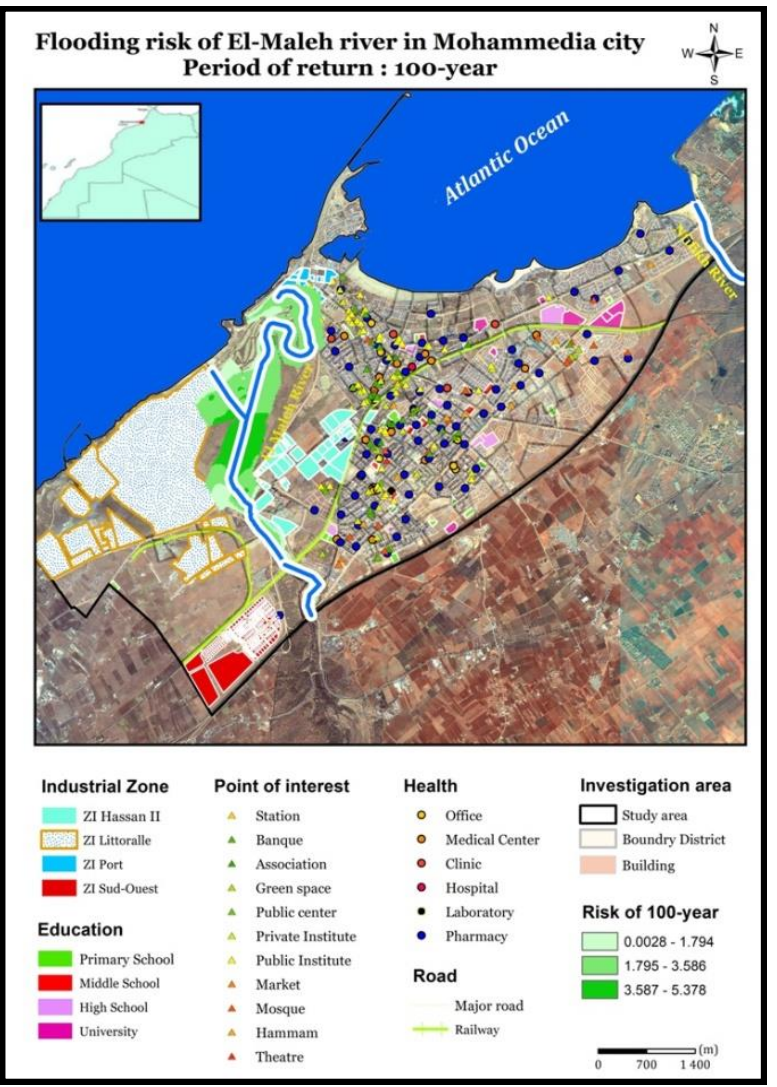

Figure 10. Flooding risk of a 100-year 


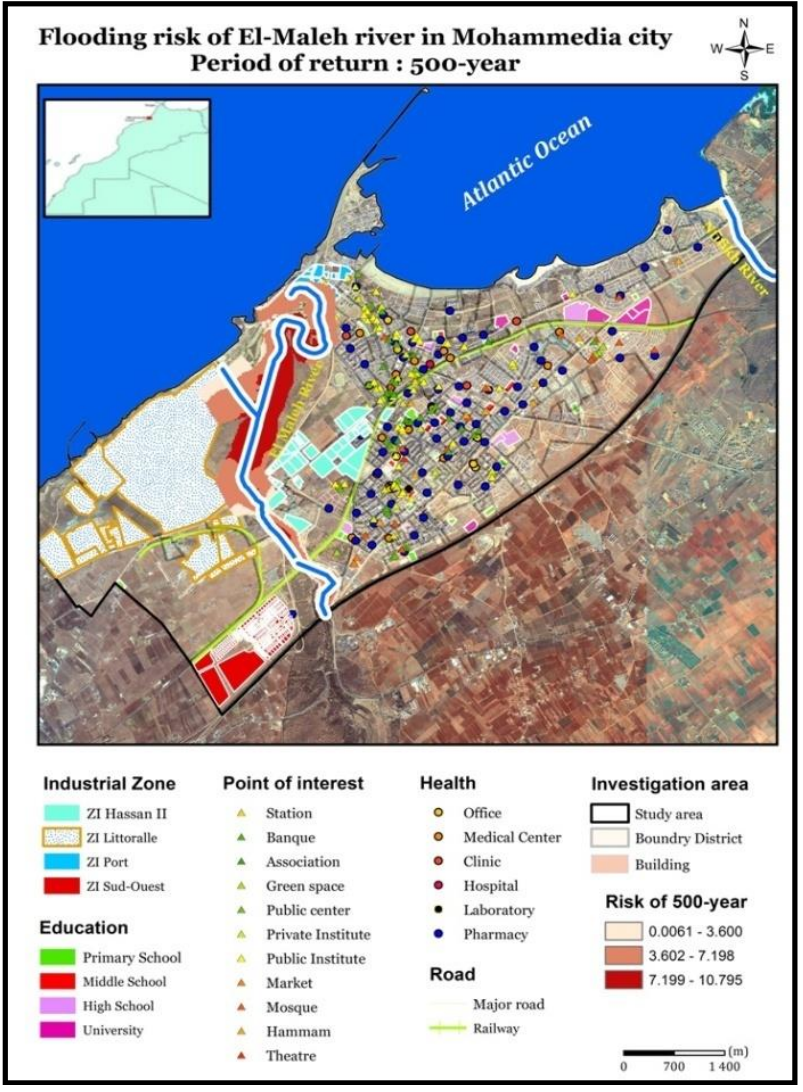

Figure 11. Flooding risk of a 500-year

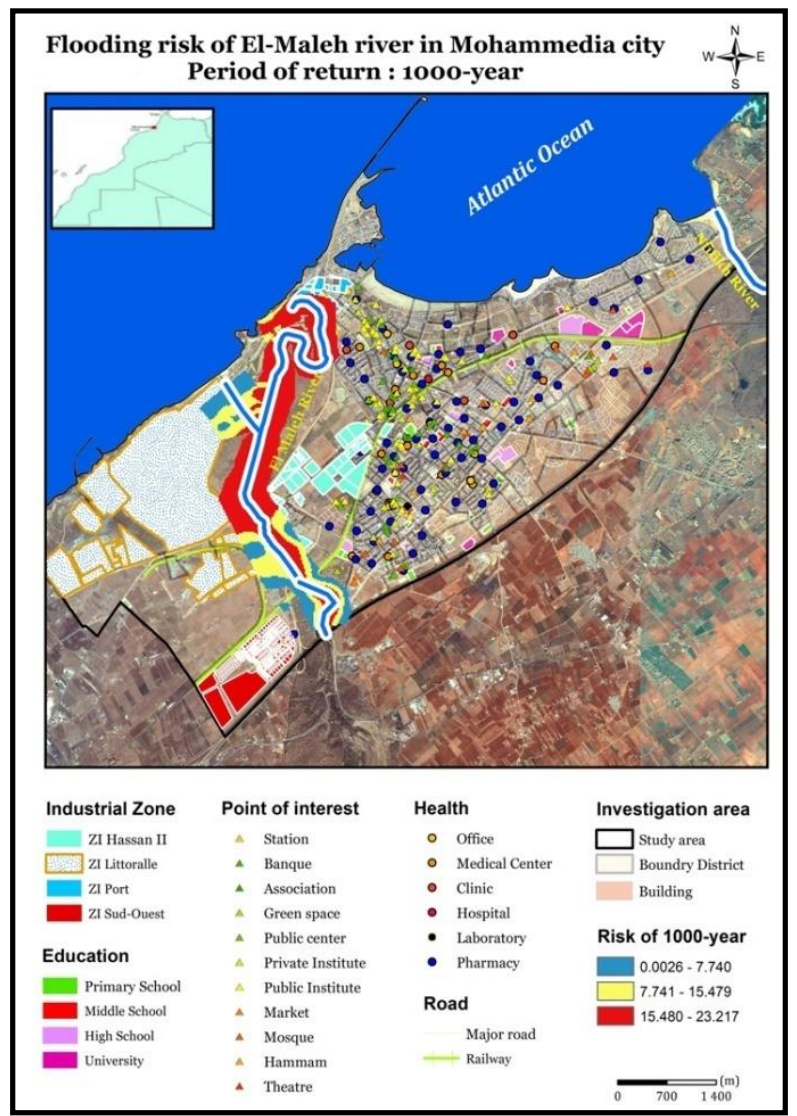

Figure 12. Flooding risk of a Millennial year
Initial analyzes proves that the petroleum quarter, the western industrial zone and the port will be the most affected by floods at different periods of return (six scenarios). Although the upper part of the city, particularly the popular districts are sheltered from simulated floods due to the high altitude (14 to $37 \mathrm{~m}$ ). Also, most points of interest, health services and education of the city are also protected because they are concentrated in the upper part (El Alia) of the city as well as the center of the city due to the altitude between 6 and $22 \mathrm{~m}$.

TABLE 1 ( LAST PAGE)

Table 1 . Areas affected by floods at different return periods

The table 1 reveals all flooded zones with the perimeter of the study area in particular the industrial zone of the port (ZP), the industrial zone of el-Maleh (ZIM) and its surroundings, as well as a built-up area (EB) and an informal housing area (ZHNR).

The overall analysis indicates that impacted zones reveal that the "ZIL" ( the district of SAMIR) and the ZP will remain slightly stable respectively from $7.34 \%$ to $10.24 \%$ and from $55.08 \%$ to $56.21 \%$. On the other hand, the "ZIM" given its proximity to the mouth of the river El maleh would be almost half submerged on a decadal flood and could reach a peak of $90 \%$ for a millennial flood.

In particular, at the onset of the five-centennial flood (Figure 11) a second zone related to the "ZIL" would be partially submerged, namely the Koutoubia deposit with: $(2653 / 43690=6.07 \%)$. And that the "EB" zone circumscribed in the delimitation of the fivecentennial flood will be totally submerged. While the "ZNHR" would be flooded with $7.26 \%$ of its total area.

Although on the millennial flood (Figure 12) a third relative zone would be flooded, notably the unit in charge of storage and trading of grains "Graderco" $(7733 / 19845=38.96 \%)$. Also, the extension of the flooded area of the Koutoubia deposit until $(8984 / 43690=20.56 \%)$. And the "EB" zones, circumscribed in the delimitation of the millennial flood, will be totally submerged. While the "ZNHR" will approach a flooding rate of about $30 \%$ of its total area.

\section{CONCLUSION}

The various produced scenarios allowed to identify the flooding of the territorial stakes in different return periods. In the presence of a heavy weather with a peak flow exceeding $1000 \mathrm{~m} / \mathrm{s}$, a Millennial flood scenario could occur and consequently the city would be in a dramatic catastrophe which could cause a serious and a very considerable consequence. It is noted that, these scenarios have been scientifically estimated which are based on calculation methods. However, they remain theoretical and partly dependent on the data collected for this purpose.

Certainly, Geospatial and digital tools are well known in the field of hydrology and spatial planning. They can be used to establish simulation scenarios and so facilitate the decision-making. 
Therefore, planning authorities should be aware of such tools to allow them understanding territorial dynamics. The purpose is to anticipate possible risks and to protect the population from any danger.

Finally, the authorities in charge of water management should provide to the urban planners a national atlas of updated flood zones in case of any territorial changes made (fitting, breakage, field action, maintenance, new technical installation, etc.).

So all the data of this atlas should be accessible through the various exchange protocols, and spatialized under national reference "Lambert Conformal Conic". Also, the detail and the genealogy of data should be geo-cataloged to know in the finest the different evolutions of the data.

\section{REFERENCES}

Chaabane M-S., 2016, The Contribution of GIS in The Management of Natural risks And Urban Planning Case Study: Management of Floods in the Region of Mohammedia. 3, 8-9.

Khouakhi A., 2008,: The Geographic Information System (GIS): a tool for assessing land at risk of coastal flooding linked to climate change. Case of the Mohammedia littoral, 5-6.

Minister Delegated To The Minister Of Energy, Mines, Water And The Environment, In Charge Of Water http://www.water.gov.ma/index.cfm?gen=true\&id=14\&ID_PA $\mathrm{GE}=50$

Morocco High Commissionership For Map, 2015, Global Census of Population and Habitat: RGPH 2014

Saloui A.,2008, XIII World Water Congress 1-4 September 2008 in Montpellier, France http://www.iwra.org/congress/2008/resource/authors/abs154_po sster.ppt.

Venkatesh M. , 2016, School of Civil Engineering, Purdue University Tutorial on using HEC-GeoRAS with ArcGIS 10.x and HECRAS Modeling ;

https://web.ics.purdue.edu/ vmerwade/education/georastutorial. pdf

Water Department - Directorate For Surveillance And Risk Prevention, 2008, Study for the realization of a mapping and a geographical information system on the major risks in Morocco, 21-22,29. 


\begin{tabular}{|c|c|c|c|c|c|c|c|c|c|c|}
\hline & \multicolumn{6}{|c|}{ 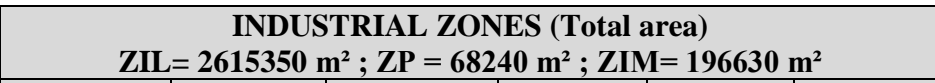 } & \multicolumn{4}{|c|}{ 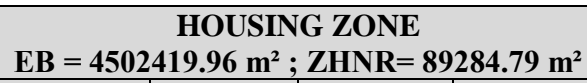 } \\
\hline & $\begin{array}{c}\text { ZIL } \\
\text { impacted } \\
\left(\mathbf{m}^{2}\right)\end{array}$ & $\begin{array}{c}\mathbf{Z P} \\
\text { impacted } \\
\left(\mathbf{m}^{2}\right)\end{array}$ & $\begin{array}{c}\text { ZIM } \\
\text { impacted } \\
\left(\mathbf{m}^{2}\right)\end{array}$ & $\begin{array}{c}\% \mathrm{ZIL} \\
\text { impacted } \\
/ \mathrm{ZIL}\end{array}$ & $\begin{array}{c}\% \mathrm{ZP} \\
\text { impacted } \\
/ \mathrm{ZP} \\
\end{array}$ & $\begin{array}{c}\% \mathrm{ZIM} \\
\text { impacted } \\
\text { / ZIM }\end{array}$ & $\begin{array}{c}\text { EB } \\
\text { impacted } \\
\left(\mathbf{m}^{2}\right)\end{array}$ & $\begin{array}{c}\% \text { EB } \\
\text { impacted } \\
/ \text { EB } \\
\end{array}$ & $\begin{array}{c}\text { ZHNR } \\
\text { impacted } \\
\left(\mathbf{m}^{2}\right)\end{array}$ & $\begin{array}{c}\% \\
\text { ZHNR } \\
\text { impacted } \\
\text { / ZHNR }\end{array}$ \\
\hline $\begin{array}{l}\text { Decadal } \\
\text { flood }\end{array}$ & 192017.73 & 37930.00 & 86332.88 & $7.34 \%$ & $55.58 \%$ & $43.91 \%$ & - & - & - & - \\
\hline $\begin{array}{l}\text { 20-year } \\
\text { flood }\end{array}$ & 193497.81 & 37461.42 & 86806.36 & $7.40 \%$ & $54.90 \%$ & $44.15 \%$ & - & - & - & - \\
\hline $\begin{array}{l}\text { 50-year } \\
\text { flood }\end{array}$ & 195937.78 & 37554.69 & 87855.55 & $7.49 \%$ & $55.03 \%$ & $44.68 \%$ & - & - & - & - \\
\hline $\begin{array}{l}\text { 100-year } \\
\text { flood }\end{array}$ & 211650.76 & 38359.5 & 94203.67 & $8.09 \%$ & $56.21 \%$ & $47.91 \%$ & - & - & - & - \\
\hline $\begin{array}{l}\text { 500-year } \\
\text { flood }\end{array}$ & 260197.27 & 37589.82 & 120021.8 & $9.79 \%$ & $55.08 \%$ & $61.04 \%$ & 46078.76 & $1.02 \%$ & 926.75 & $7.26 \%$ \\
\hline $\begin{array}{l}\text { Millenal } \\
\text { flood }\end{array}$ & 274194.54 & 37637.04 & 172660.79 & $10.24 \%$ & $55.15 \%$ & $87.81 \%$ & 64676.65 & $1.44 \%$ & 27561.43 & $30.87 \%$ \\
\hline
\end{tabular}

Table 1. Areas affected by floods at different return periods 